\title{
Impact of DOM composition on bacterial lipids and community structure in estuaries
}

\author{
H. Rodger Harvey ${ }^{1, *}$, Rachael Y. Dyda ${ }^{1}$, David L. Kirchman ${ }^{2}$ \\ ${ }^{1}$ Chesapeake Biological Laboratory, University of Maryland Center for Environmental Science, Box 38, Solomons, \\ Maryland 20688, USA \\ ${ }^{2}$ College of Marine Studies, 700 Pilottown Road, University of Delaware, Lewes, Delaware 19958, USA
}

\begin{abstract}
This study explored the relationship between lipid composition and bacterial community structure during growth of natural bacterial communities in the Chesapeake and Delaware bays. Experiments examined the effect of the addition of protein, glucose and site-specific $>1 \mathrm{kDa}$ ultrafiltered DOM (dissolved organic matter) on bacterial fatty acids and bacterial community structure determined by fluorescence in situ hybridization (FISH). We examined 3 environments over an estuarine gradient comprising a freshwater marsh, the anoxic waters of the central Chesapeake Bay channel, and the Lower Delaware Bay, to encompass a range of bacterial communities and to determine how each community might respond to varying DOM sources in terms of both community structure and lipid signatures. The results demonstrated that fatty acids produced by bacteria depend on carbon source, with consistent trends regardless of physical environment and initial community structure. In contrast to the fatty acid signatures, the FISH results suggested that no single group of bacteria responded consistently to the addition of DOM, either as individual substrates or as complex natural material. The results suggest that while fatty acid synthesis appears strongly associated with dissolved substrates, assignments of specific bacterial groups to fatty acid signatures are not possible at broad phylogenetic levels.
\end{abstract}

KEY WORDS: Bacteria - Fatty acids $\cdot$ Compound-specific isotopes $\cdot$ FISH $\cdot$ Estuaries $\cdot$ Bacterial community structure

Resale or republication not permitted without written consent of the publisher

\section{INTRODUCTION}

Bacteria play a central role in biogeochemical cycles, especially in the uptake, transformation and release of organic matter in aquatic systems (Kirchman 2000, Carlson 2002). Bacteria act as both catalysts for the breakdown of particles and as the consumers of dissolved components, playing the major role in the mineralization of dissolved organic matter. This process is both efficient and adaptable (del Giorgio \& Cole 1998), with only a small fraction of the organic matter produced escaping to be preserved in sediments and soils. Identification of naturally occurring bacterial communities and knowledge of how each community responds to varied organic matter inputs is crucial to understanding the role of bacteria in the cycling of dissolved organic matter and the contribution of bacteria to the organic matter pool.

The phylogenetic composition of bacterial communities in aquatic systems is now becoming clear through the application of methods that focus on 1 phylogenetic marker, 16S rRNA. These studies have demonstrated that bacterial communities can differ substantially among aquatic systems even at rather broad phylogenetic levels. For example, lakes are dominated by Betaproteobacteria and Actinobacteria, whereas Alphaproteobacteria are abundant in the oceans; Cytophaga-like bacteria are often abundant in both freshwaters and marine systems (Glöckner et al. 1999). The distribution of these bacterial groups along the salinity gradient of estuaries like the Chesapeake and Delaware mirrors that of lakes and the oceans (Bouvier 
\& del Giorgio 2002, Kirchman et al. 2005), yet salinity is only one of several factors thought to shape the composition of bacterial communities. Although the controls on bacterial community composition are not fully understood, the quantity and quality of organic material as substrates are likely to be important factors.

Cellular components other than RNA have also been used as taxonomic markers of microbes (including both bacteria and Archaea) and as indicators of their potential contribution to organic material in natural environments. Membrane lipids, especially fatty acids, have received significant attention (Ratledge \& Wilkenson 1988, Harvey \& Macko 1997, Zou et al. 2004), as the presence of bacteria has often been inferred from data on odd- and branched-chain fatty acids known to be synthesized by bacteria in culture (Kaneda 1991), and specific hydroxy fatty acids have also been attributed to bacteria in the oceans (Wakeham 1999). Unique lipids have been identified in bacteria responsible for specialized processes, for example the ladderane lipids in bacteria carrying out anaerobic nitrate reduction (Sinninghe Damsté et al, 2002). Many members of the kingdom Archaea also have distinctive lipid signatures because of the unique sn-2, 3 rather than sn-1,2 stereochemistry of the glycerol moiety and the presence of ether-bound membrane lipids with isoprenoidal carbon skeletons rather than ester-linked alkyl lipids (Koga et al. 1998). The lipid signatures of Archaea have even been used to follow the distribution of groups which have not yet been successfully cultured (Bian et al. 2001, Sturt et al. 2004). Although it has long been suggested that bacterial community structure can be examined through fatty acid profiling (Guckert et al. 1985), these acids vary greatly among culturable bacteria and others such as the branched acids do not appear to be universal (Kaneda 1991). Harvey and Macko (1997) documented this complication, noting that while concentrations of specific odd- and branched-chain bacterial fatty acids were higher during active microbial degradation of phytoplankton, branched acid concentration corresponded poorly with bacterial carbon calculated from cellular abundance. As a result, it remains unclear if specific lipids can provide quantitative measures of bacterial biomass and if there is any association between bacterial lipids and their community structure as revealed by RNA-based methods.

In this study, we explored the relationship between lipid composition and bacterial community composition in experiments with bacterial communities of the Chesapeake and Delaware Bays. These experiments examined the effect of the addition of different organic compounds on bacterial lipid distribution and bacterial community structure as determined by fluorescence in situ hybridization (FISH). The organic compounds included dissolved protein, glucose and site-specific $>1 \mathrm{kDa}$ ultrafiltered DOM. The environments covered an estuarine gradient: a freshwater marsh, the anoxic waters of the central Chesapeake Bay channel, and the Lower Delaware Bay which is open to the coastal ocean. On selected samples, compound-specific isotopic analysis was performed on fatty acids to ascertain that substrates were directly incorporated and used for cellular synthesis. The overall goal was to investigate the response of natural bacterial communities in these diverse environments and to examine the potential relationship between bacterial cell membrane lipids and community structure.

\section{MATERIALS AND METHODS}

Study sites. The Delaware estuary is a highly urbanized system extending $212 \mathrm{~km}$ from the bay mouth to the upstream limit of tidal influence at Trenton, New Jersey. The estuary is generally well mixed, except during high river-flow in early spring, with a classic 2-layer circulation pattern (Sharp et al. 1986) and changing DOM composition, depending on location (Mannino \& Harvey 1999). Sampling took place from August 27 to 31,2002 , at 2 locations in the Delaware characterized by differing physiochemical characteristics. The Marsh site is a freshwater marsh (salinity =2) and is heavily influenced by tidal cycles, with significant amounts of humic and organic material. The Lower Bay site is near the mouth of the estuary and characterized by high salinity (salinity $=31.5$ ) and high productivity (Sharp et al. 1982, Pennock \& Sharp 1986). The third site comprised the deep channel of the nearby Chesapeake Bay which undergoes seasonal anoxia (salinity $=15$ ). Anoxic waters were present within $3 \mathrm{~m}$ of the surface during the time of sampling (G. Luther unpubl. data).

Experimental incubations and sampling. At the Lower Bay and Marsh sites, water was obtained from $1 \mathrm{~m}$ depth using a peristaltic pump and was filtered inline through Gelman cartridge filters of 3.0 and $0.2 \mu \mathrm{m}$ pore size. At the Chesapeake Bay site, water was collected similarly from $12 \mathrm{~m}$ to obtain anoxic waters. Prior to water collection, clean 20 liter carboys used in the incubations were rinsed with 21 of $0.2 \mu \mathrm{m}$ filtered water three times for a total rinse volume of 6 l. Carboys were filled by filtering directly into carboys with $18 \mathrm{l}$ of $0.2 \mu \mathrm{m}$-filtered water plus a $2 \mathrm{l}$ inoculum of $3.0 \mu \mathrm{m}$ filtered water.

We applied 3 treatments plus controls (no addition) at each site: (1) $1 \mathrm{mg} \mathrm{l}^{-1}$ bovine serum albumin (BSA), (2) $10 \mu \mathrm{M}$ glucose, and (3) >1 kDa dissolved organic matter (DOM). DOM was collected and concentrated from 201 of water at each site by ultrafiltration immedi- 
ately prior to incubations and was added to the carboys to effectively double $>1 \mathrm{kDa}$ DOM concentrations. The $>1 \mathrm{kDa}$ DOM filtrate was obtained using an Amicon DC-10L tangential-flow ultrafiltration unit with the S10N1 filter (Mannino \& Harvey 1999). Following the carbon addition, all carboys were thoroughly mixed and incubated in the dark for $48 \mathrm{~h}$ at ambient water temperatures using a flow-through system on deck. At 24 and $48 \mathrm{~h}$, waters from each treatment and control were subsampled by filtration onto combusted $47 \mathrm{~mm}$ GF/F filters (using vacuum-filtration) for lipid analysis, and immediately frozen until analysis. For microscopic determination of bacterial abundance, biovolume and taxonomic identity, whole-water subsamples were fixed with $2 \%(\mathrm{v} / \mathrm{v})$ paraformaldehyde and refrigerated overnight. Bacteria were then filtered onto $0.2 \mu \mathrm{m}$ polycarbonate filters and stored at $-20^{\circ} \mathrm{C}$ until analysis.

Bacterial numbers and community structure. Bacterial abundance and cell volume were determined using a semi-automated microscopy and imageanalysis approach (Cottrell \& Kirchman 2004) after staining with 4', 6-diamidino-2 phenylindole (DAPI). Bacterial community structure was examined by FISH with oligonucleotide probes. Water for this analysis was preserved in fresh paraformaldehyde ( $2 \%$, final concentration) overnight and then filtered through $0.2 \mathrm{~mm}$ polycarbonate filters. The FISH procedure was as described previously (Cottrell \& Kirchman 2004). In brief, the relative abundance of major phylogenetic groups was determined using CY3-labeled (MWG Biotech) Probe Eub338 for bacteria, Alf968 for Alphaproteobacteria, Bet42a for Betaproteobacteria, Gam42a for Gammaproteobacteria and CF319a for Cytophaga-like bacteria. Unlabeled competitor probes were also used for distinguishing Betaproteobacteria and Gammaproteobacteria. A negative control probe was used to examine non-specific binding. After staining with DAPI, the sample was mounted with Vectashield and Citifluor (1:4) and examined with a semi-automated image-analysis system coupled to an Olympus epifluorescence microscope (Cottrell \& Kirchman 2004).

Lipid analysis. Lipids were extracted from the $3.0 \mu \mathrm{m}$ inoculum waters at 24 and $48 \mathrm{~h}$ time points of incubations from all 3 stations, as outlined in Mannino and Harvey (1999). Briefly, samples were ultrasonically extracted in a mixture of $\mathrm{CH}_{2} \mathrm{Cl}_{2}: \mathrm{MeOH}$ (1:1) in solvent-rinsed glass test tubes with Teflon-lined caps for $45 \mathrm{~min}$ followed by extraction overnight at $4^{\circ} \mathrm{C}$. Total lipids were extracted 3 times and consolidated, and the solvent was removed using rotary evaporation. Internal standards included non-decanoic acid and $5 \alpha$-cholestane which were added after consolidation of total lipid extracts. Neutral lipids were derivatized at $50^{\circ} \mathrm{C}$ for 15 min using bis(trimethylsilyl)trifluoroacetamine [BSTFA] amended with $25 \%$ pyridine. Fatty acids were methylated using boron trifluoride in methanol at $70^{\circ} \mathrm{C}$ for $30 \mathrm{~min}$. Polar and neutral lipids were quantified using capillary gas chromatography (HP5890 II). Lipids were separated using a J\&W Scientific DB-5 fused-silica column $(60 \mathrm{~m}$ length $\times 0.32 \mathrm{~mm}$ inner diameter $\times 0.25 \mu \mathrm{m}$ film thickness) with quantification by flame-ionization detection. Samples were injected in the splitless mode (oven temperature $50^{\circ} \mathrm{C}$; injector at $225^{\circ} \mathrm{C}$ ), with hydrogen as the carrier gas. Structural identification utilized an Agilent 6890 GC coupled to an Agilent 5973N mass selective detector using identical conditions as above but with helium as the carrier gas. Double-bond positions of monounsaturated fatty acids were identified by GC-MS analysis as the dimethyl disulfide (DMDS) adducts (Nichols et al. 1986).

To validate that fatty acid distributions were the result of biosynthesis of added substrates at the Lower Bay site, natural isotopic abundance of individual fatty acids for control and protein incubations was determined by GC coupled to a stable-isotope ratio massspectrometer (IRMS). The GC conditions and column were identical to that described above, with the eluent passing through a combustion interface and isotopic abundance of $\mathrm{CO}_{2}$ determined on a VG Optima mass spectrometer. The ${ }^{13} \mathrm{C} /{ }^{12} \mathrm{C}$ ratio is expressed in \%o relative to the Peedee belemnite standard by the conventional notation. Typical precision $( \pm 1$ SD) for sample components as measured by repeated injections ranged from 0.2 to $0.5 \%$.

\section{RESULTS}

\section{Bacterial growth and response to substrates}

Total bacterial abundance in the $3.0 \mu \mathrm{m}$ filtered water used for regrowth experiments was similar in the marsh $\left(1.9 \times 10^{9}\right.$ cells $\left.^{-1}\right)$ and lower bay sites $\left(1.4 \times 10^{9}\right.$ cells $\left.\mathrm{l}^{-1}\right)$, and lower in anoxic Chesapeake Bay waters $\left(4.0 \times 10^{8}\right.$ cells $\left.\mathrm{l}^{-1}\right)$. Bacterial abundance rapidly increased (2- to over 7 -fold) over the first $24 \mathrm{~h}$ of incubation (Table 1). After $24 \mathrm{~h}$, bacterial abundance was typically higher in treatments with substrate addition compared to control incubations, except for the Lower Bay site where bacteria in the untreated control were higher than in treatments. In general, bacterial abundance and cell volume varied among treatments, although glucose and protein incubations at all sites had the highest bacterial abundances (cells $\mathrm{l}^{-1}$ ) and cell volume $\left(\mu \mathrm{m}^{3}\right)$. DOM amendments showed the smallest overall increase in bacterial abundance over 24 and $48 \mathrm{~h}$ at all stations. Bacterial carbon remained the same or increased at 48 versus $24 \mathrm{~h}$ time points, with the exception of the Marsh site which showed a significant decrease in all incubations at $48 \mathrm{~h}$ (Table 1). 
Table 1. Bacterial abundance, biovolumes and organic carbon in sample waters and regrowth experiments for the 3 sites in the

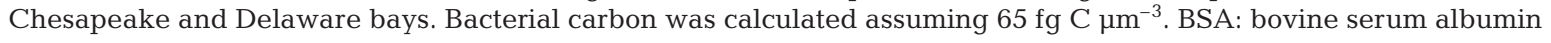

\begin{tabular}{|c|c|c|c|c|c|c|c|c|c|}
\hline \multirow{2}{*}{ Site } & \multirow{2}{*}{ Inoculum } & \multicolumn{4}{|c|}{$24 \mathrm{~h}$} & \multicolumn{4}{|c|}{$48 \mathrm{~h}$} \\
\hline & & Control & BSA & Glucose & DOM & Control & BSA & Glucose & DOM \\
\hline \multicolumn{10}{|l|}{ Chesapeake Bay (anoxic) } \\
\hline Total abundance $\left(\times 10^{9} \mathrm{l}^{-1}\right)$ & 0.401 & 0.924 & 2.044 & 7.399 & 1.308 & 0.887 & 6.749 & 6.181 & 1.427 \\
\hline Biovolume $\left(\mu m^{3}\right)$ & 0.0432 & 0.0665 & 0.0991 & 0.0674 & 0.0573 & 0.0456 & 0.0663 & 0.0751 & 0.0479 \\
\hline Bacterial carbon $\left(\mu \mathrm{g} \mathrm{C}^{-1}\right)$ & 1.124 & 3.996 & 13.172 & 32.409 & 4.873 & 2.627 & 29.105 & 30.167 & 4.446 \\
\hline \multicolumn{10}{|l|}{ Lower Delaware Bay } \\
\hline Total abundance $\left(\times 10^{9} \mathrm{l}^{-1}\right)$ & 1.390 & 6.295 & 3.802 & 4.799 & 3.168 & 2.803 & 8.447 & 2.524 & 3.208 \\
\hline Biovolume $\left(\mu \mathrm{m}^{3}\right)$ & 0.0377 & 0.0404 & 0.0581 & 0.0403 & 0.0417 & 0.0502 & 0.0483 & 0.0825 & 0.0619 \\
\hline Bacterial carbon $\left(\mu \mathrm{g} \mathrm{C} \mathrm{^{-1 } )}\right.$ & 3.402 & 16.548 & 14.349 & 12.579 & 8.586 & 9.144 & 26.534 & 13.540 & 12.899 \\
\hline \multicolumn{10}{|l|}{ Marsh (freshwater) } \\
\hline Total abundance $\left(\times 10^{9} \mathrm{l}^{-1}\right)$ & 1.856 & 6.590 & 13.629 & 11.462 & 6.622 & 1.463 & 1.578 & 1.692 & 1.815 \\
\hline Biovolume $\left(\mu \mathrm{m}^{3}\right)$ & 0.0280 & 0.0466 & 0.0467 & 0.0766 & 0.0453 & 0.0328 & 0.0593 & 0.0492 & 0.0438 \\
\hline Bacterial carbon $\left(\mu \mathrm{g} \mathrm{C} \mathrm{^{-1 } )}\right.$ & 3.372 & 19.981 & 41.388 & 57.049 & 19.483 & 3.117 & 6.079 & 5.410 & 5.173 \\
\hline
\end{tabular}

The Marsh site was unique among the incubations in that it showed the greatest increase in bacterial numbers after $24 \mathrm{~h}$, but a rapid decline by the $48 \mathrm{~h}$ time point. Such decreases in bacterial numbers were dramatic ( $>10$-fold) and not seen in other incubations. The rapidity of such changes suggests the presence of micrograzers which were not fully excluded by the $3.0 \mu \mathrm{m}$ filter and responded to the rapid increase in bacterial numbers over the first $24 \mathrm{~h}$. Lipid analysis of $48 \mathrm{~h}$ Marsh incubations confirmed the presence of tetrahymanol, a specific biomarker for bacterivorous ciliates (Harvey \& McManus 1991). Because of the presence of grazers, these samples were excluded from analyses of bacterial carbon and lipid profiles.

\section{Bacterial community and substrate response}

The percentage of cells detected by the general FISH bacterial probe (EUB338) ranged from $70 \%$ in anoxic Chesapeake waters to 83 and $87 \%$ in the Lower Bay and Marsh sites, respectively (Fig. 1). Within each site, all 4 major phylogenetic groups were observed in significant numbers. Bacterial community structure, as revealed by FISH analysis, suggested that the 3 sites contained different resident communities. Chesapeake waters contained similar distributions among the 4 groups, ranging from $24 \%$ for Alphaproteobacteria to $33 \%$ of total cell abundance for the Cytophaga-like bacteria. In the Lower Bay site, Alphaproteobacteria was more prevalent, accounting for $48 \%$ of total abundance, with the next most abundant group being Cytophaga-like bacteria (21\%). Alphaproteobacteria and Betaproteobacteria abundance in the Lower Bay were similar to those in Chesapeake Bay, making up 21 and $24 \%$ of total abundance, respectively. Gamma- proteobacteria accounted for $10 \%$ of cell abundance in the freshwater marsh waters, with the 3 remaining groups roughly equal in abundance (Fig. 1).

Over the $48 \mathrm{~h}$ incubation period, the bacterial community changed in both unamended controls and treatments with various substrate additions (Fig. 1). The most dramatic shifts were in the additions to anoxic Chesapeake incubations. After $48 \mathrm{~h}$, the Cytophaga-like bacteria dominated the glucoseamended incubations (84\% of total) and the Gammaproteobacteria group dominated the incubations with added protein $(76 \%)$. Substrate additions to Lower Bay waters led to more rapid growth of Alphaproteobacteria (Fig. 1) and an overall decrease in Betaproteobacteria. The freshwater marsh treatments showed a varied pattern of growth among each group, but a consistent increase in the abundance of Betaproteobacteria was seen in all incubations. By $48 \mathrm{~h}$ in the marsh incubations, bacterial numbers were impacted by micrograzers with a sharp decrease in abundance not seen in controls or other treatments.

Bacterial communities in the control incubations and DOM-amended incubations corresponded closely at each of the 3 sites, despite the differences among bacteria communities in each location at time zero. In anoxic Chesapeake waters, Gammaproteobacteria grew fastest (to $42 \%$ of total abundance in DOM incubation) with a decrease in Alphaproteobacteria and Cytophaga-like groups. In the Lower Bay, Betaproteobacteria became a minor component $(<5 \%$ of abundance in the control and DOM), whereas Alphaproteobacteria increased substantially in the DOM treatment (Fig. 1). The Marsh site DOM addition showed a similar increase in Alphaproteobacteria (from 18 to $48 \%$ ); other groups in controls and the DOM treatment did not change substantially. 


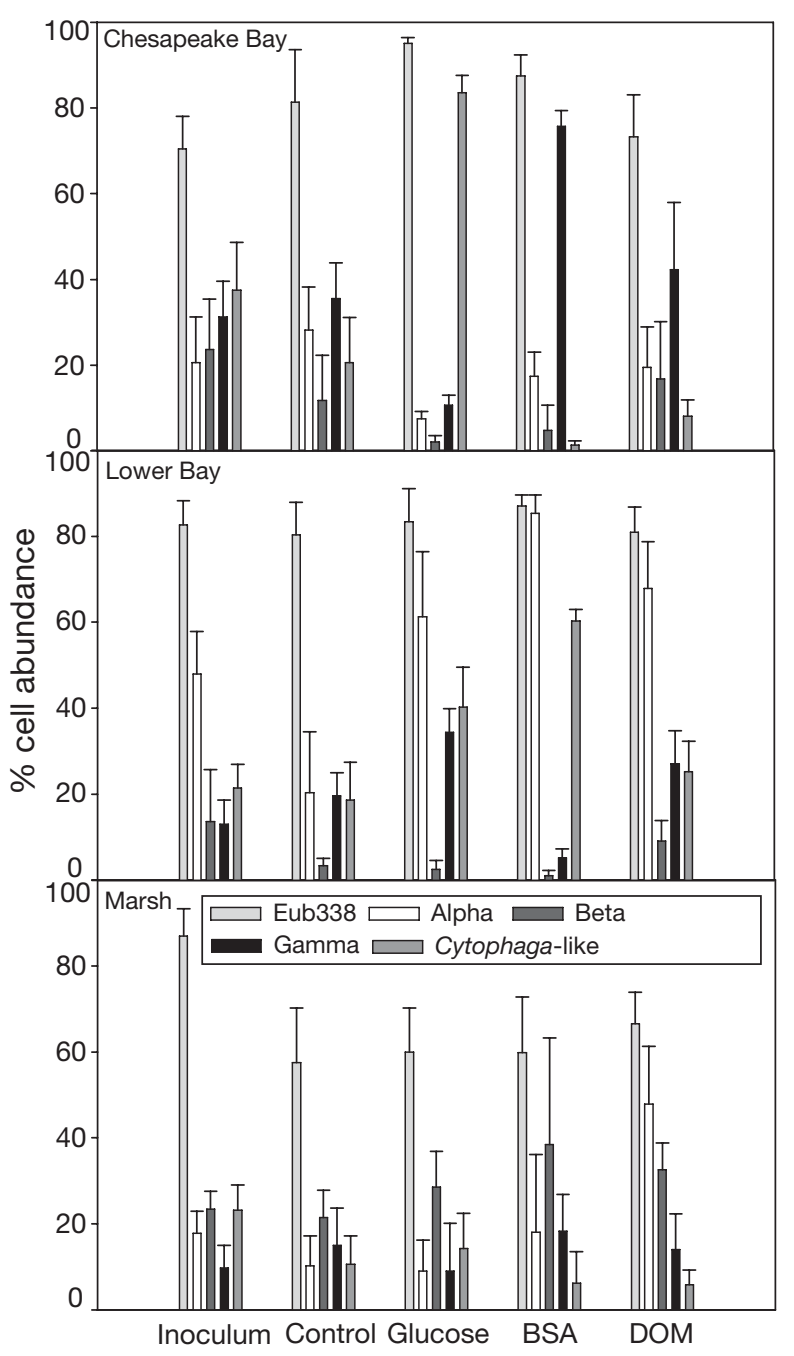

Fig. 1. Bacterial community structure at Chesapeake Bay (anoxic) Lower Delaware Bay (open to ocean), and freshwater marsh described by $16 \mathrm{~S}$ fluorescence in situ hybridization (FISH) analysis. Results are shown for all 3 sites after $48 \mathrm{~h}$ incubations as percentage of cell abundance. Eub338: general bacterial probe; alpha, beta and gamma: subdivisions of Proteobacteria

\section{Fatty acids during bacterial regrowth}

The amount and distribution of fatty acids relative to the inoculum waters changed within $24 \mathrm{~h}$ of substrate addition at all sites. With the single exception of the Lower Bay control, fatty acid concentrations increased significantly among all sites and treatments (Table 2). The Lower Bay location showed the greatest changes in concentration range relative to the inoculum water, from a 1.6-fold increase in total fatty acids for DOM additions (from 79 to $125 \mathrm{ng}$ fame $\mu \mathrm{g} \mathrm{C} \mathrm{C}^{-1}$ ) to over 10 fold (860 ng fame $\mu \mathrm{g} \mathrm{C}^{-1}$ ) for glucose-amended waters. Among all 3 sites total fatty acid concentrations were generally highest in glucose and protein addi- tions at $24 \mathrm{~h}$, but showed more variability by $48 \mathrm{~h}$. The Marsh site had the highest fatty acid concentration among any treatments but this result should be interpreted with caution, since some fraction included ciliates and probably other micrograzers. The increase in polyunsaturated acids in the marsh samples, a type of fatty acid rarely found in estuarine and coastal marine bacteria, further supports the occurrence of significant eukaryotic growth in these incubations by $48 \mathrm{~h}$.

An important observation was that shifts in fatty acid distribution during bacterial growth were substratespecific, regardless of sample site (Table 2). Saturated fatty acids, dominated the initial fatty acid distribution at all sites, comprising 37 to $60 \%$ of the fatty acids depending on location (Fig. 2A). After 24 h, control and DOM incubations showed increases in monounsaturated fatty acids and branched acids, with saturated and monounsaturated fatty acids contributing about equally. By 48 h, however, the lipid distribution had shifted, and monounsaturated fatty acids, in particular $16: 1 \Delta 9$ and $18: 1 \Delta 11$, made up the majority of the lipids in both incubations (32 to $57 \%$ ). Monounsaturated

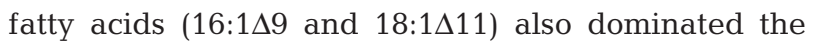
glucose-amended incubations, making up 56 to $72 \%$ of the total fatty acids at all 3 sites (Table 2). The most dramatic change in fatty acid composition was seen for protein-amended incubations, in which branched- and odd-chain fatty acids increased substantially at all 3 locations (Fig. 2). Within $24 \mathrm{~h}$, the 15:1 $\Delta 4$ and 15:0 iso acids alone increased from $8 \%$ to at least $58 \%$ of the total fatty acids in the protein treatments for freshwater, anoxic and lower estuarine environments, relative to the initial lipid composition. By 48 h, however, concentrations of these fatty acids had decreased for the marsh incubation (a possible consequence of grazing), but remained at over $60 \%$ of total fatty acids in the Chesapeake and Lower Bay sites.

Although protein additions elicited the synthesis of specific branched fatty acid among all environments, a number of site-specific shifts were also observed. At the anoxic Chesapeake site, fatty acids concentrations in the control incubation nearly doubled from 24 to $48 \mathrm{~h}$, yet the total concentration of fatty acids in the DOM treatment remained relatively constant (Table 2A). Glucose-amended incubations also remained relatively constant in terms of fatty acid content after $24 \mathrm{~h}$, with little exchange among major fatty acid groups (Fig. 2A). In contrast, Lower Bay waters showed a continual increase in total fatty acids over $48 \mathrm{~h}$ for control and DOM incubations, but remained lower than either of the 2 other sites despite similar fatty acid class-distributions (Fig. 2B). The glucose addition to Lower Bay waters resulted in the highest fatty acid concentrations of any site (860 ng fatty acid methyl esters [FAME] $\mu \mathrm{g} \mathrm{C}^{-1}$ ) if $48 \mathrm{~h}$ Marsh samples 
Table 2. Concentration and distribution of fatty acids in sample waters and regrowth experiments for (A) Chesapeake Bay, (B) Lower Delaware Bay, (C) Freshwater marsh. coel: coeluting peaks; nf: not found; $\Delta$ : no. double-bond position from carboxyl end; br: branched; i: iso; a: anteiso. Concentrations calculated using both cell abundance and cell volume: assuming $65 \mathrm{fg} \mathrm{C} \mathrm{m}^{-3}$

\begin{tabular}{|c|c|c|c|c|c|c|c|c|c|}
\hline \multirow{2}{*}{$\begin{array}{l}\text { Fatty acid } \\
\left(\text { ng FAME } \mu g^{-1} \mathrm{C}\right)\end{array}$} & \multirow{2}{*}{ Inoculum } & \multicolumn{4}{|c|}{$-24 \mathrm{~h}$} & \multicolumn{4}{|c|}{$48 \mathrm{~h}$} \\
\hline & & Control & BSA & Glucose & DOM & Control & BSA & Glucose & DOM \\
\hline \multicolumn{10}{|c|}{ (A) Chesapeake Bay (anoxic) } \\
\hline $13: 0 \mathrm{i}$ & 0.0 & $\mathrm{nf}$ & 0.6 & 0.0 & $\mathrm{nf}$ & $\mathrm{nf}$ & 2.0 & 0.1 & $\mathrm{nf}$ \\
\hline $14: 0$ & 7.0 & 17.4 & 6.2 & 10.6 & 13.1 & 26.5 & 5.4 & 10.0 & 8.9 \\
\hline $15: 1 \Delta 4$ & 0.4 & 1.6 & 55.3 & 0.2 & $\mathrm{nf}$ & 3.1 & 76.3 & 0.3 & $\mathrm{nf}$ \\
\hline $15: 0 \mathrm{i}$ & 1.6 & 4.6 & 86.4 & 0.8 & 2.8 & 8.9 & 125.3 & 1.9 & 2.7 \\
\hline $15: 0 \mathrm{a}$ & 0.7 & $\mathrm{nf}$ & coel & 0.4 & 2.1 & $\mathrm{nf}$ & 0.9 & 0.6 & 1.9 \\
\hline $15: 0$ & 0.3 & 1.9 & 1.8 & 0.3 & 2.8 & 5.5 & 3.9 & 0.3 & 4.4 \\
\hline $16: 4$ & $\mathrm{nf}$ & $\mathrm{nf}$ & $\mathrm{nf}$ & $\mathrm{nf}$ & $\mathrm{nf}$ & $\mathrm{nf}$ & $\mathrm{nf}$ & $\mathrm{nf}$ & $\mathrm{nf}$ \\
\hline $16: 0 \mathrm{br}$ & 0.7 & 1.8 & 1.4 & 0.8 & 1.7 & 6.3 & 1.8 & $\mathrm{nf}$ & 2.0 \\
\hline $16: 1 \Delta 9$ & 16.1 & 46.2 & 23.2 & 134.9 & 31.4 & 79.3 & 39.1 & 128.3 & 45.3 \\
\hline $16: 2$ & 1.4 & 1.4 & 1.2 & 32.9 & 1.9 & 3.0 & 1.0 & 26.3 & 3.8 \\
\hline $16: 1 \Delta 11$ & 3.1 & 4.0 & 1.4 & 1.8 & 3.0 & 7.5 & 1.4 & 1.8 & 5.1 \\
\hline $16: 0$ & 32.1 & 69.1 & 19.3 & 97.1 & 51.0 & 105.3 & 25.8 & 109.2 & 54.2 \\
\hline $17: 1 \Delta 9$ & $\mathrm{nf}$ & $\mathrm{nf}$ & coel & $\mathrm{nf}$ & $\mathrm{nf}$ & nf & 5.4 & $\mathrm{nf}$ & $\mathrm{nf}$ \\
\hline $17: 0 \mathrm{i}$ & $\mathrm{nf}$ & $\mathrm{nf}$ & 1.8 & $\mathrm{nf}$ & 0.7 & $\mathrm{nf}$ & 4.0 & $\mathrm{nf}$ & 0.8 \\
\hline $18: 2+18: 4$ & 0.4 & 0.7 & 0.5 & 0.4 & 0.7 & 1.4 & 0.6 & 0.6 & 0.8 \\
\hline $18: 2$ & 0.9 & 4.2 & 2.0 & 1.2 & 3.9 & 5.9 & 7.1 & 1.2 & 3.6 \\
\hline $18: 1 \Delta 9$ & 2.9 & 20.9 & 3.9 & 8.4 & 10.9 & 52.4 & 9.4 & 9.8 & 10.5 \\
\hline $18: 1 \Delta 11$ & 6.4 & 33.5 & 31.6 & 137.3 & 54.5 & 74.1 & 57.9 & 125.9 & 76.3 \\
\hline $18: 2$ & 0.4 & 1.2 & 1.0 & 11.5 & 1.6 & 3.3 & 1.4 & 10.2 & 2.8 \\
\hline $18: 0$ & 7.2 & 14.4 & 2.1 & 7.4 & 12.9 & 41.1 & 2.7 & 7.9 & 12.7 \\
\hline $19: 1 \Delta 13$ & 0.5 & 1.8 & 1.1 & 3.0 & 3.4 & 6.2 & 3.6 & 5.5 & 5.9 \\
\hline $20: 4$ & 0.5 & 0.8 & 0.1 & 0.1 & 0.5 & 2.2 & 0.2 & 0.3 & 0.4 \\
\hline $20: 5$ & 1.2 & 5.3 & 1.0 & 1.3 & 1.3 & 13.4 & 1.0 & 1.8 & 2.0 \\
\hline $22: 5$ & 0.9 & 0.3 & 0.0 & 0.1 & 0.1 & 1.4 & 0.0 & 0.2 & 0.1 \\
\hline $22: 6$ & 0.2 & 3.6 & 0.4 & 0.8 & 0.9 & 6.8 & 0.4 & 1.2 & 1.0 \\
\hline $22: 0$ & $\mathrm{nf}$ & $\mathrm{nf}$ & coel & $\mathrm{nf}$ & coel & $\mathrm{nf}$ & $\mathrm{nf}$ & $\mathrm{nf}$ & $\mathrm{nf}$ \\
\hline Total & 91.8 & 249.7 & 250.2 & 464.8 & 213.2 & 473.5 & 389.9 & 459.8 & 261.6 \\
\hline \multicolumn{10}{|c|}{ (B) Lower Delaware Bay (open to ocean) } \\
\hline $13: 0 \mathrm{i}$ & 0.1 & 0.0 & 5.6 & 0.4 & 0.1 & 0.2 & 7.9 & 1.3 & 0.5 \\
\hline $14: 0$ & 6.3 & 2.9 & 9.5 & 38.3 & 8.5 & 11.5 & 9.6 & 40.3 & 11.2 \\
\hline $15: 1 \Delta 4$ & 0.7 & 0.4 & 65.9 & 2.3 & 1.2 & 1.7 & 64.4 & 3.4 & 1.9 \\
\hline $15: 0 \mathrm{i}$ & 1.9 & 0.7 & 99.6 & 4.9 & 1.5 & 3.8 & 103.8 & 12.7 & 4.6 \\
\hline $15: 0 \mathrm{a}$ & 0.7 & coel & 1.4 & 2.2 & 0.9 & 2.5 & 1.9 & 4.2 & 3.0 \\
\hline $15: 0$ & 0.8 & 1.0 & 2.2 & 21.2 & 3.0 & 4.3 & 2.2 & 14.7 & 4.9 \\
\hline $16: 4$ & 0.2 & $\mathrm{nf}$ & $\mathrm{nf}$ & $\mathrm{nf}$ & $\mathrm{nf}$ & $\mathrm{nf}$ & $\mathrm{nf}$ & $\mathrm{nf}$ & $\mathrm{nf}$ \\
\hline 16:0br & 0.9 & 0.3 & 1.1 & 2.5 & 0.7 & 1.6 & 1.6 & 2.5 & 1.4 \\
\hline $16: 1 \Delta 9$ & 10.9 & 5.0 & 25.9 & 225.8 & 17.0 & 33.0 & 19.4 & 165.1 & 40.7 \\
\hline $16: 2$ & 0.8 & 0.1 & 0.4 & 123.3 & 0.6 & 1.0 & 0.3 & 41.7 & 1.7 \\
\hline $16: 1 \Delta 11$ & 0.7 & 0.5 & 1.7 & 4.5 & 0.9 & 2.6 & 1.7 & 3.7 & 2.7 \\
\hline $16: 0$ & 18.4 & 14.6 & 25.0 & 206.7 & 31.2 & 3.0 & $\mathrm{nf}$ & 88.0 & 17.7 \\
\hline $17: 1 \Delta 9$ & $\mathrm{nf}$ & $\mathrm{nf}$ & coel & $\mathrm{nf}$ & $\mathrm{nf}$ & $\mathrm{nf}$ & coel & $\mathrm{nf}$ & $\mathrm{nf}$ \\
\hline $17: 0 \mathrm{i}$ & $\mathrm{nf}$ & $\mathrm{nf}$ & 2.3 & $\mathrm{nf}$ & $\mathrm{nf}$ & $\mathrm{nf}$ & 6.1 & $\mathrm{nf}$ & $\mathrm{nf}$ \\
\hline $18: 2+18: 4$ & 1.7 & 0.6 & 3.0 & 4.6 & 2.6 & 3.6 & 5.7 & 3.2 & 5.2 \\
\hline $18: 2$ & 1.8 & 0.5 & 1.3 & 2.1 & 1.4 & 1.9 & 0.6 & 1.3 & 2.1 \\
\hline $18: 1 \Delta 9$ & 4.7 & 1.7 & 4.9 & 7.2 & 5.0 & 8.3 & 3.8 & 5.0 & 9.6 \\
\hline $18: 1 \Delta 11$ & 8.4 & 6.6 & 33.0 & 109.1 & 26.9 & 47.4 & 41.9 & 81.0 & 58.9 \\
\hline $18: 2$ & 0.3 & 0.3 & 0.6 & 7.8 & 0.3 & 0.2 & 1.0 & 3.2 & 1.4 \\
\hline $18: 0$ & 3.3 & 5.9 & 5.5 & 14.5 & 10.8 & 7.5 & 2.5 & 8.8 & 11.0 \\
\hline $19: 1 \Delta 13$ & 0.5 & 0.9 & 2.0 & 4.6 & 1.6 & 6.2 & 6.7 & 4.5 & 6.8 \\
\hline $20: 4$ & 0.7 & 0.1 & 0.4 & 0.7 & 0.3 & 0.4 & 0.5 & 1.1 & 0.7 \\
\hline $20: 5$ & 4.8 & 0.9 & 2.7 & 7.4 & 1.5 & 3.3 & 2.3 & 4.6 & 2.6 \\
\hline $22: 5$ & 0.3 & 0.0 & 0.1 & 0.3 & 0.1 & 0.1 & 0.2 & 1.2 & 0.3 \\
\hline $22: 6$ & 4.8 & 0.6 & 1.5 & 4.2 & 1.0 & 2.5 & 1.5 & 2.6 & 1.3 \\
\hline $22: 0$ & 0.0 & 0.1 & $\mathrm{nf}$ & 25.9 & 0.2 & coel & $\mathrm{nf}$ & $\mathrm{nf}$ & 0.6 \\
\hline Total & 78.9 & 47.8 & 311.5 & 860.4 & 124.7 & 163.7 & 306.6 & 522.7 & 207.9 \\
\hline
\end{tabular}


Table 2 (continued)

\begin{tabular}{|c|c|c|c|c|c|c|c|c|c|}
\hline \multirow{2}{*}{$\begin{array}{l}\text { Fatty acid } \\
\left(\text { ng FAME } \mu g^{-1} \text { C) }\right.\end{array}$} & \multirow{2}{*}{ Inoculum } & \multicolumn{4}{|c|}{$-24 \mathrm{~h}$} & \multicolumn{4}{|c|}{$48 \mathrm{~h}$} \\
\hline & & Control & BSA & Glucose & DOM & Control & BSA & Glucose & DOM \\
\hline \multicolumn{10}{|c|}{ (C) Freshwater marsh } \\
\hline $13: 0 \mathrm{i}$ & 0.2 & 1.3 & 2.4 & 0.6 & $\mathrm{nf}$ & 2.0 & 5.8 & 1.3 & 0.9 \\
\hline $14: 0$ & 3.6 & 7.0 & 3.5 & 4.8 & 8.2 & 66.7 & 24.4 & 44.2 & 66.2 \\
\hline $15: 1 \Delta 4$ & 0.9 & 6.2 & 37.9 & 1.8 & 4.9 & 20.1 & 71.4 & 8.7 & 15.1 \\
\hline $15: 0 \mathrm{i}$ & 2.6 & 13.0 & 59.8 & 5.5 & 13.3 & 69.4 & 83.6 & 69.8 & 30.4 \\
\hline $15: 0 a$ & 1.5 & 3.7 & 1.9 & 2.6 & 2.8 & 14.8 & 4.6 & 14.9 & 8.8 \\
\hline $15: 0$ & 0.3 & 1.7 & 0.8 & 1.6 & 2.1 & 12.0 & 4.7 & 12.6 & 14.4 \\
\hline $16: 4$ & 1.8 & 0.7 & 0.2 & coel & coel & 2.2 & 0.7 & 0.9 & 3.3 \\
\hline $16: 0 \mathrm{br}$ & 0.2 & 3.7 & 3.1 & 1.8 & 2.9 & 37.1 & 24.1 & 19.6 & 38.7 \\
\hline $16: 1 \Delta 9$ & 7.4 & 17.2 & 14.6 & 69.9 & 23.9 & 97.5 & 47.4 & 128.6 & 118.5 \\
\hline $16: 2$ & 0.7 & 1.8 & 0.8 & 1.8 & 1.7 & 27.0 & 10.6 & 5.8 & 25.6 \\
\hline $16: 1 \Delta 11$ & 0.5 & 0.9 & 0.7 & 1.1 & 1.4 & 13.1 & 4.5 & 6.6 & 13.5 \\
\hline $16: 0$ & 40.5 & 27.7 & 13.6 & 36.2 & 34.7 & 97.0 & 12.4 & 78.8 & 137.5 \\
\hline $17: 1 \Delta 9$ & $\mathrm{nf}$ & coel & 7.3 & 0.1 & coel & coel & 48.4 & $\mathrm{nf}$ & $\mathrm{nf}$ \\
\hline $17: 0 \mathrm{i}$ & 0.2 & 1.6 & 3.4 & 0.3 & 0.6 & 19.4 & 41.0 & 14.0 & 3.3 \\
\hline $18: 2+18: 4$ & 1.4 & 2.2 & 1.2 & 2.0 & 2.1 & 22.1 & 14.6 & 27.8 & 14.9 \\
\hline $18: 2$ & 0.6 & 0.7 & 0.5 & 0.7 & 1.3 & 17.4 & 14.0 & 53.7 & 22.8 \\
\hline $18: 1 \Delta 9$ & 3.1 & 3.4 & 1.2 & 2.3 & 4.6 & 47.9 & 27.0 & 57.5 & 51.0 \\
\hline $18: 1 \Delta 11$ & 3.9 & 31.1 & 29.3 & 65.0 & 27.4 & 72.5 & 40.9 & 101.0 & 77.7 \\
\hline $18: 2$ & 0.1 & 0.1 & 0.4 & 0.3 & 0.6 & 21.2 & 7.7 & 15.8 & 23.3 \\
\hline $18: 0$ & 7.2 & 4.1 & 2.1 & 2.3 & 7.5 & 38.2 & 15.4 & 33.6 & 31.1 \\
\hline $19: 1 \Delta 13$ & 0.2 & 3.5 & 2.0 & 3.7 & 2.8 & 23.0 & coel & 41.6 & 11.1 \\
\hline $20: 4$ & 0.2 & 0.8 & 0.3 & 0.6 & 0.8 & 45.1 & 104.7 & 160.8 & 29.3 \\
\hline $20: 5$ & 2.2 & 7.4 & 3.1 & 2.8 & 6.9 & 213.7 & 201.9 & 208.6 & 182.6 \\
\hline $22: 5$ & 0.1 & 0.5 & 0.2 & 0.3 & 0.4 & 17.0 & 37.3 & 92.1 & 12.1 \\
\hline $22: 6$ & 3.8 & 9.1 & 2.6 & 1.9 & 10.3 & 295.7 & 121.9 & 235.6 & 268.5 \\
\hline $22: 0$ & 0.5 & 0.1 & coel & 0.0 & coel & 2.4 & 0.9 & 2.8 & 1.6 \\
\hline Total & 87.5 & 158.4 & 201.6 & 215.1 & 170.8 & 1425.3 & 1115.6 & 1557.7 & 1320.3 \\
\hline
\end{tabular}

with grazers are excluded. For the freshwater Marsh site, both protein and glucose treatments had similar amounts of total fatty acids (Table 2C), but with sharply different distributions of fatty acids (Fig. 2). Large increases were apparent in Marsh waters at $48 \mathrm{~h}$, but the presence of micrograzers complicates interpretation of the values observed.

\section{Isotopic signatures of fatty acids}

Selected samples of $48 \mathrm{~h}$ incubations were used to examine the incorporation of substrates into fatty acids. For the protein incubations, the unique (-10.5\%) isotopic signature of BSA as the model protein should allow even small amounts of protein incorporation to be observed compared to the ${ }^{13} \mathrm{C}$ values of DOM typical of these locales (i.e. -24.5 to -19.6 ; Harvey \& Mannino 2001). The stable-isotope values of fatty acids in the control incubations range from -24.8 to $-34.7 \%$, with variability that might be expected from communities reliant on the DOM remaining in the incubations (Table 3). In the protein incubations, however, the patterns were not uniform as might be expected from a single carbon source. Relative to the control, overall shifts in stable-isotope values of fatty acids synthesized during the protein incubation ranged from +1.30 to $-8 \%$, reflecting a selective incorporation of protein carbon into fatty acids during bacterial growth. The shift of $-8 \%$ relative to isotopic values for fatty acids in the control incubation make it apparent that 15:1 $\Delta 4$ and 15:0 iso fatty acids were synthesized using protein as a substrate. The stable isotope values of other fatty acids $(14: 0,18: 1 \Delta 11)$ in the protein incubation changed by approximately $4 \%$ relative to the stable isotope values of individual fatty acids from the control incubation, indicating that these fatty acids were synthesized by several groups of bacteria using multiple substrates. The stable isotope values of $12: 0,16: 1 \Delta 9,16: 0$ and $22: 1 \Delta 13$ changed by $<2 \%$ in the protein versus control incubations, suggesting that bacteria used naturally occurring DOM as the carbon source in the synthesis of these fatty acids.

\section{Bacterial lipid and carbon}

Using the cell abundance and biovolume data at 24 and $48 \mathrm{~h}$, we also examined the relationship between fatty acids synthesized during growth and bacterial 

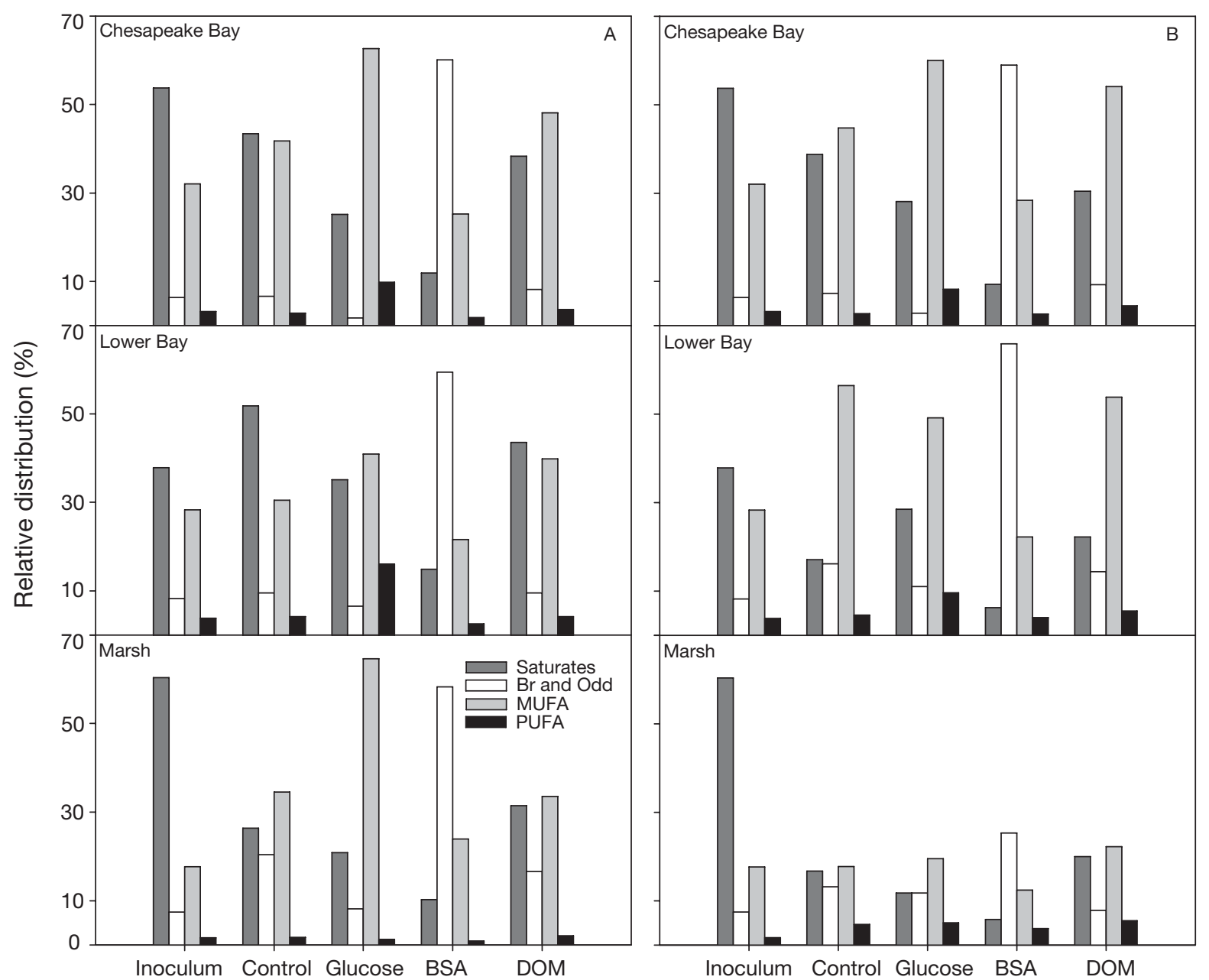

Fig. 2. Distribution of major fatty acid classes at (A) $24 \mathrm{~h}$ and (B) $48 \mathrm{~h}$ at all 3 sites. Inoculum waters at time 0 are shown for comparison. Additional polyunsaturated fatty acids seen in all Marsh treatments at $48 \mathrm{~h}$ were excluded. MUFA, PUFA: monounsaturated and polyunsaturated acids, respectively. Branched- (Br) and odd- (Odd) chain fatty acids are combined

Table 3. Carbon-isotopic (\%) values for selected fatty acids synthesized in control and protein-amended incubations of Lower Delaware Bay waters. nd: not determined

\begin{tabular}{|lccccccc|}
\hline Fatty acid & $14: 0$ & $15: 1 \Delta 4^{\mathrm{a}}$ & $15: 0 \mathrm{i}^{\mathrm{a}}$ & $16: 1 \Delta 9$ & $16: 0$ & $18: 1 \Delta 11$ & $22: 1 \Delta 13$ \\
\hline Control & -24.8 & nd & -26.7 & -27.8 & -25.4 & -31.3 & -34.7 \\
Protein & -21.4 & -19.8 & -18.7 & -26.5 & -26.7 & -27.3 & -32.8 \\
Difference & -3.4 & - & 8.0 & -1.3 & 1.3 & 4.0 & -1.99 \\
asotope signature for BSA used in additions was & $-10.5 \pm 0.1$ \\
\hline
\end{tabular}

carbon. Bacteria responded rapidly to glucose additions and for all 3 locations, the glucose and protein treatments showed the greatest contribution to bacterial carbon. Both glucose and protein-amended incubations had the largest cell volume (maximum $0.0991 \mu^{3}$, Table 1). Inoculum waters, control incuba- tions and DOM treatment at all sites were lower and more variable. DOM additions did not lead to greater bacterial carbon at all sites until $48 \mathrm{~h}$. Using summed fatty acid concentrations, the relationship between total fatty acids of natural bacterial communities after regrowth and bacterial carbon is shown in Fig. 3 for all 3 sites and substrates. Trace amounts of several algal fatty acids (e.g. 20:5, 22:6) were also observed in $3.0 \mu \mathrm{m}$ filtered waters (Table 2A-C) and thus PUFAs containing more than 2 double bonds were excluded from the regression analyses to avoid overlap. Values for the Marsh site (Fig. 3C) at $48 \mathrm{~h}$ were also excluded, since fatty acids could not be attributed to bacteria alone. Among the 3 sites, the anoxic waters of Chesapeake Bay showed 

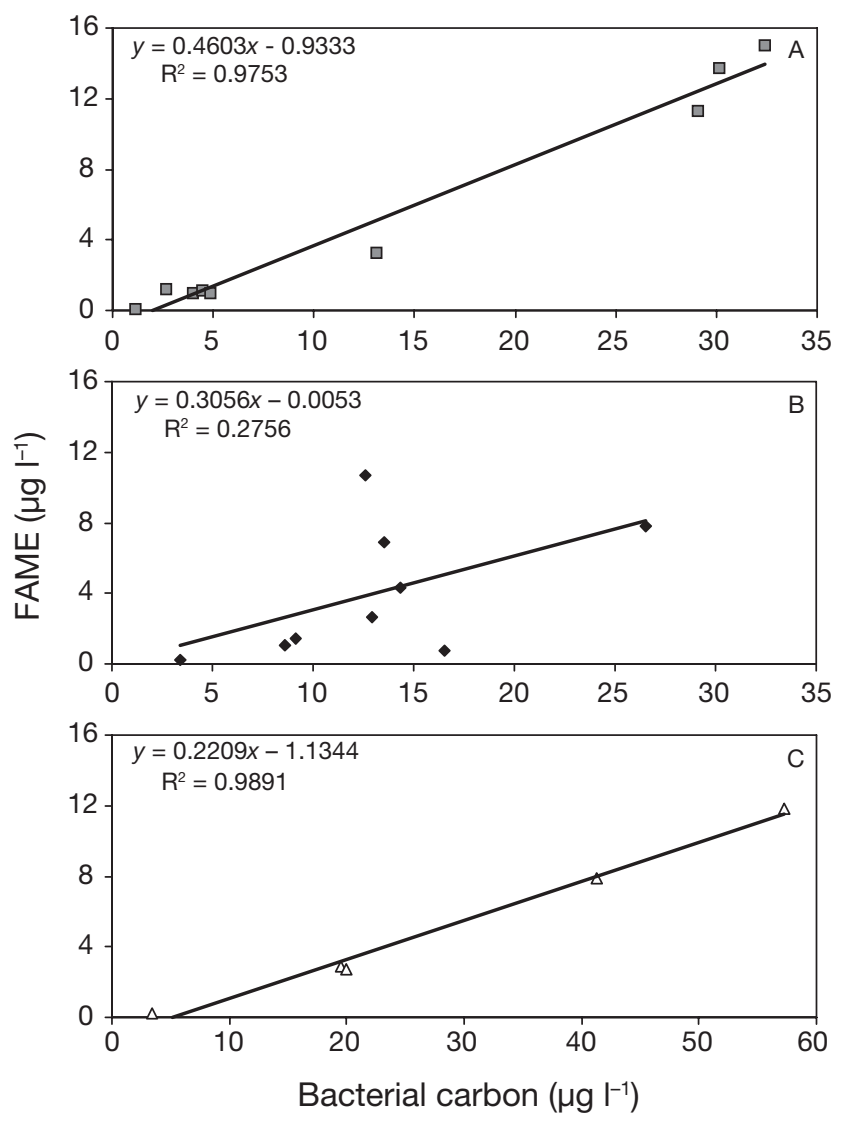

Fig. 3. Relationship between concentration of total fatty acids (fatty acid methylesters, FAME) and calculated bacterial carbon during bacterial regrowth for (A) Chesapeake Bay, (B) Lower Delaware Bay and (C) freshwater marsh; $48 \mathrm{~h}$ time points excluded from Marsh panel because of presence of microheterotrophs. $p=0.05$ in all cases

the most rapid increase in fatty acids with increasing bacterial carbon (Fig. 3A). Individually, the anoxic Chesapeake Bay site and the Marsh site showed a very close relationship between bacterial carbon and fatty acid concentration, with $\mathrm{R}^{2}$ values of 0.974 and 0.989 , respectively. The correspondence in the Lower Bay between fatty acid concentration and bacterial carbon was much lower $\left(R^{2}=0.275\right)$, and skewed by the high lipid content of the glucose incubation at $24 \mathrm{~h}$ and the low lipid content of the $24 \mathrm{~h}$ control. When these time points were excluded, $R^{2}$ value increased to 0.975 . Perhaps more importantly, there remained a good relationship between fatty acid and bacterial carbon $\left(\mathrm{R}^{2}=\right.$ 0.608) even when all 3 sites and substrates were combined (Fig. 4). This was despite the large range in bacterial carbon, lipid concentrations and the inclusion of 3 distinct environments, and suggests that the relationship observed (FAME $\left[\mu g \mathrm{l}^{-1}\right]=0.2662 \times$ bacterial carbon $\left[\mu \mathrm{g} \mathrm{l}^{-1}\right]+0.3383$ ) can be used to estimate the lipid contribution of bacteria among diverse environments.

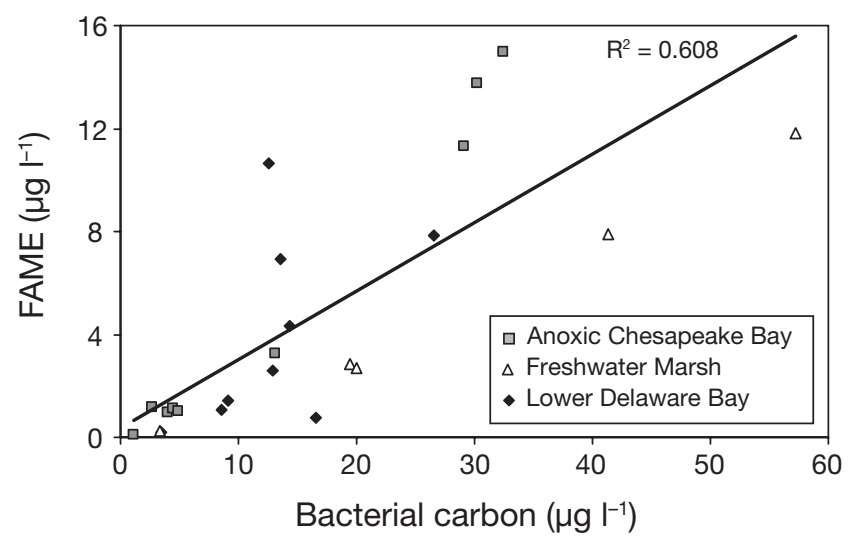

Fig. 4. Relationship between concentration of total fatty acids and calculated bacterial carbon at the 3 study sites after bacterial growth on controls or with supplemented DOM

\section{DISCUSSION}

The composition and quantity of substrates in DOM are thought to have major impacts on bacterial community structure, influencing both biomass and growth rates of the total bacterial assemblages (Carlson 2002). Some evidence suggests that bacterial groups are particularly adept at using select components of the DOM pool. For example, Cytophaga-like bacteria are thought to be proficient in using proteins and other high molecular weight DOM, based on pure culture studies (Kirchman 2002) and limited experiments with natural bacterial communities (Cottrell \& Kirchman 2000, Kirchman et al. 2004). Alphaproteobacteria, including the abundant subgroup SAR11 (Morris et al. 2002), appear to use glucose, amino acids and perhaps other low molecular weight compounds (Cottrell \& Kirchman 2000, Malmstrom et al. 2005). Some members of the Gammaproteobacteria may be opportunistic, and have been found to outcompete other groups in response to high DOM concentrations (Fuchs et al. 2000). We did observe a large increase in Gammaproteobacterial abundance after a glucose addition in 1 experiment. Our results, however, suggest that the situation is more subtle and complex, with a least some portion of the bacterial community responding to various organic compounds, depending on the site.

Some influence of substrate on bacterial community structure was apparent from the current results, perhaps best seen in the control and DOM supplemented incubations at each site. These incubations all showed similar distributions among the 4 bacterial groups, suggesting that the addition of DOM supplemented those substrates being used, with little influence on the overall bacterial community (Fig. 1). Yet, when a readily utilized substrate such as glucose was provided, community structure at each site varied sub- 
stantially, suggesting that the substrate alone (or at least a single substrate) was not responsible for structuring the observed communities. Cottrell \& Kirchman (2004) suggested that DOM and other 'bottom-up factors' are not the sole factors controlling the distribution of the major aquatic bacterial groups in the Delaware estuary. Given the large differences among the 3 sites (e.g. dissolved oxygen, salinity, DOM character), more detailed comparisons will be required to resolve the multiple factors that structure bacterial communities.

While the distribution and concentration of fatty acids and other cellular membrane components are widely used for examining sources of carbon (e.g. Volkman 1986, Harvey 1994, Wakeham et al. 2003), data on specific natural bacterial communities are rare. Typical filtration of particles in aquatic environments often captures not only bacteria, but also phytoplankton (autotrophic carbon) as cells or fragments, grazers and a variety of detrital material. Characterization of isolated bacteria has provided crucial insight, but it is well known that culturable bacteria differ substantially from the uncultured bacteria that dominate natural waters (Suzuki et al. 1997, Giovannoni \& Rappé 2000), and even the chemotaxonomy of culturable bacteria can show great diversity (Suzuki et al. 1997). Consequently, it has been difficult to link ubiquitous components such as fatty acids to specific bacterial phylogenetic groups in natural environments.

The fatty acid distribution observed, and the dramatic changes with various substrates, suggests that lipid synthesis in growing bacterial communities responds similarly to available organic substrates. The case of protein additions clearly shows the consistent and substantial biosynthesis of branched fatty acids among 3 physical environments and varied bacterial communities. This consistency suggests that those bacteria which grew in response to dissolved protein rely on similar fatty acid synthesis pathways. Culture studies have shown that branched chain primers (e.g. 2- or 3-methyl butyrate) can be readily used by bacteria in place of acetate for fatty acid synthesis, leading to the production of C15 and C17 branched fatty acids (see review by Fulco 1983). The protein used (BSA) does not contain appreciable amounts of branched acids, but these are readily generated by deamidation and oxidative decarboxylation of the amino acids leucine, isoleucine and valine during protein hydrolysis (Chang \& Fulco 1973, see Kaneda 1991). Given the rapid production of branched fatty acids as a major end product of cellular fatty acid synthesis, these amino acids appear to be preferentially used as starting material for subsequent fatty acid synthesis.

A major finding of this study is the consistency observed in lipid synthesis amongst several dissolved substrates and controls which was not reflected in bacterial community structure as measured by FISH patterns
(Fig. 1). It is widely recognized that that the bacterial groups defined by the FISH probes we used are quite broad and encompass many bacterial species (Giovannoni \& Rappé 2000). As a result, any comparison of specific fatty acids and bacterial community distribution must take into account the potential for significant overlap in bacterial metabolic capacities among each of the 4 major bacterial groups. This is best seen in the protein incubations, where the bacterial community structure varied among the 3 sites while the fatty acid composition was nearly identical. The Lower Bay and Marsh treatments support this most clearly, with the 2 dominant branched fatty acids (15:0 iso and 15:1 $\Delta 4)$ present in high concentrations (Table 2B,C). Based on the empirical relationship found between total fatty acid concentrations and bacterial abundance (and thus carbon), the amount of branched acids greatly exceeds that which could be attributed to any single phylogenetic group. This would support the commonly held idea that branched fatty acid synthesis is widespread and common to multiple bacterial groups. Further support can be seen in the Chesapeake Bay protein additions, where the high abundance of Gammaproteobacteria was sufficient to supply all the branched fatty acid seen, yet this bacterial group was a minor contributor in Lower Bay protein incubations, which also showed high-branched fatty acid concentrations. This lack of concordance between fatty acid distributions and bacterial community structure was also seen, albeit less obviously, with glucose incubations in which mono-

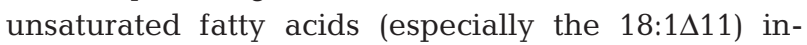
creased substantially at all 3 sites without comparable changes among bacterial groups. The sum of these differences among fatty acid concentration, distribution and bacterial community structure suggests that fatty acid synthesis in response to specific substrates is shared among several bacterial phylogenetic groups, and that these groups are common to multiple bacterial groups as defined by FISH probes. As a result, while fatty acid synthesis appears strongly associated with response to substrate, assignments of specific bacterial groups to fatty acid signatures are not possible at these broad phylogenetic levels.

Although varied fatty acid composition is not uncommon amongst bacteria, less is known about the relationship of fatty acid composition and phylogeny. It does appear that bacteria isolated from similar environments and with similar phylogeny can display varied lipid signatures. In work by Mergaert et al. (2001), 137 strains of bacteria isolated from oligotropohic Arctic and Antarctic waters were divided into clusters based on numerical analysis of their fatty acid distributions. The clusters were then compared with 16S rRNA-sequencing of a portion of the isolated bacterial strains. Despite the fact that all bacterial were grown under identical conditions 
(in this case on agar slants), a number of closely related bacteria showed varied fatty acid patterns, including the absence or presence of various branched acids. Among the 23 strains subject to 16S rRNA-sequencing, many showed considerable differences in fatty acid profiles in comparison with their nearest phylogenetic neighbors. Together with the results shown here for broader phylogenetic grouping and substrate response, we can speculate that while phylogenetic diversity allows broad fatty acid synthesis patterns under similar conditions, the presence of specific substrates provides the opportunity for uptake and synthesis of specific fatty acids among several bacterial groups. As a result, branched fatty acids traditionally considered a signature of bacterial organic carbon may indeed represent bacterial carbon, but cannot be considered ubiquitous markers. Instead, these fatty acids appear to represent multiple groups of bacteria in natural communities which respond to available carbon primers for lipid synthesis.

Isotopic signatures of individual fatty acids can be used to explore carbon sources, in particular when the added substrates are significantly different from the potential substrates present in estuarine waters. Following the $\beta$-oxidation pathway, biosynthesis of fatty acids typically yields carbon isotopic values that are depleted by up to $7 \%$ compared to the initial substrate (DeNiro \& Epstein, 1977), although depletions usually range from -3 to $-6 \%$ o (Boschker et al. 1999, Boschker \& Middelburg 2002). Stable isotope analysis of individual fatty acids from the $48 \mathrm{~h}$ Lower Bay control and protein incubations suggests that incorporation of protein was also variable, with a complex pattern of synthesis (Table 3). Fatty acids in the control incubations had ${ }^{13} \mathrm{C}$ isotope values ranging from -24.8 to $-34.7 \%$, reflecting the utilization of a varied suite of compounds present in natural DOM, and varied capabilities of the diverse community for uptake.

Given the strong selection for protein utilization as seen in branched fatty acid synthesis, it was surprising that the addition of dissolved protein to estuarine waters did not result in a uniform pattern of isotope values. Relative to the control, stable isotope values of fatty acids synthesized during the protein incubation shifted from +1.30 to $-8 \%$, reflecting a selective incorporation of protein carbon into specific cellular fatty acids during bacterial growth. Such depletion has been observed in other studies (e.g. Abraham et al. 1998, Fang et al. 2002), but what is noteworthy is the variability associated with the fractionation in the present experiments. Certainly those fatty acids initiated from protein amino acids (odd-chain and branched acids) were also those that came to dominate the fatty acid composition in protein treatments at all 3 sites. Yet other acids were also produced, including those which do not appear to rely on protein carbon, based on isotopic values (e.g. 16:0). Although recent work has shown that variable isotope patterns are possible during fatty acid synthesis (Teece et al. 1999, Zhang et al. 2003), the range of isotopic values seen here suggests that not all newly synthesized fatty acids incorporated carbon from the added dissolved protein, but instead a subset of fatty acids was synthesized utilizing available DOM already present (Table 3). Although a varied response in the presence of labile substrates supports the use of specific fatty acids as indices of substrate utilization, it also suggests that caution is required in assignments of bacterial utilization based solely on the observed fatty acid composition. Thus, more selective measures are required to assess the role of specific bacterial groups and their potential contribution to fatty acid signatures in environmental samples.

The results presented here show that bacteria among a number of phylogenic groups can rapidly respond to various substrates, and yet have similar lipid signatures. Adaptable fatty acid synthesis among phylogenetically different groups of bacteria was apparent, particularly during protein utilization where branched fatty acids were the dominant fatty acid produced. In conclusion,

- Fatty acids produced by bacteria depend upon the carbon source, with consistent trends seen regardless of physical environment and community structure. The breadth of fatty acids produced and the results of the isotopic analysis of individual fatty acids confirm that multiple pathways are operative

- Bacterial community structure, as revealed by FISH, confirmed that physical environments maintained different resident communities, and no singular group of bacteria responded preferentially to the addition of DOM as either individual substrate or complex natural material

- Taken together, the comparison of lipid biosynthesis and community-structure analysis suggests that fatty acid synthesis in response to specific substrates is shared among several bacterial phylogenetic groups. Changes in the diversity in bacterial communities and fatty acid synthesis over short time scales reflect both the changing availability of substrates and the rapid adaptation of the microbial community to changes in environmental variables.

Acknowledgements. This work was supported by the Chemical Oceanography program of the NSF. We thank M. Suzuki for very helpful discussions and comments on an early version of the manuscript, anonymous reviewers for constructive comments, and members of MOGEL for technical assistance. Contribution No. 3917, The University of Maryland Center for Environmental Science. 


\section{LITERATURE CITED}

Abraham WR, Hesse C, Pelz O (1998) Ratios of carbon isotopes in microbial lipids as an indicator of substrate usage. Appl Environ Microbiol 64:4202-4209

Bian LQ, Hinrichs KU, Xie TM, Brassell SC, Iversen H, Fossing H, Jørgensen BB, Hayes JM (2001) Algal and archaeal polyisoprenoids in a recent marine sediment: molecular isotopic evidence for anaerobic oxidation of methane. Geochem Geophys Geosyst 2:(2000GC000112)

Boschker HTS, Middelburg JJ (2002) Stable isotopes and biomarkers in microbial ecology. FEMS Microbiol Ecol 40: 85-95

Boschker HTS, de Brouwer JFC, Cappenberg TE (1999) The contribution of macrophyte-derived organic matter to microbial biomass in salt-marsh sediments: stable carbon isotope analysis of microbial markers. Limnol Oceanogr 44:309-319

Bouvier TC, del Giorgio PA (2002) Compositional changes in free-living bacterial communities along a salinity gradient in two temperate estuaries. Limnol Oceanogr 47:453-470

Carlson CA (2002) Production and removal processes. In: Hansell DA, Carlson CA (eds) Biogeochemistry of marine dissolved organic matter. Academic Press, San Diego, CA, p 91-151

Chang NC, Fulco AJ (1973) The effects of temperature and fatty acid structure on lipid metabolism in bacillus licheniformis. Biochim Biophys Acta 296:287-299

Cottrell MT, Kirchman DL (2000) Natural assemblages of marine Proteobacteria and members of the CytophagaFlavobacter cluster consuming low- and high- molecularweight dissolved organic matter. Appl Environ Microbiol 66:1692-1697

Cottrell MT, Kirchman DL (2004) Single-cell analysis of bacterial growth, cell size, and community structure in the Delaware estuary. Aquat Microb Ecol 34:139-149

del Giorgio PA, Cole JJ (1998) Bacterial growth efficiency in natural aquatic systems. Annu Rev Ecol Syst 29:503-541

DeNiro MJ, Epstein S (1977) Mechanism of carbon isotope fractionation associated with lipid synthesis. Science 197: 261-263

Fang J, Barcelona MJ, Abrajano T, Nogi Y, Kato C (2002) Isotopic composition of fatty acids of extremely piezophilic bacteria from the Mariana Trench at 11,000 m. Mar Chem 80:1-9

Fuchs BM, Zubkov MV, Sahm K, Burkill PH, Amann R (2000) Changes in community composition during dilution cultures of marine bacterioplankton as assessed by flow cytometric and molecular biological techniques. Environ Microbiol 2:191-201

Fulco AJ (1983) Fatty acid metabolism in bacteria. Prog Lipid Res 22:133-160

Giovannoni SJ, Rappé MS (2000) Evolution, diversity and molecular ecology of marine prokaryotes, In: Kirchman DL (ed) Microbial ecology of the ocean. Wiley-Interscience, New York, p 47-84

Glöckner FO, Fuchs BM, Amann R (1999) Bacterioplankton compositions of lakes and oceans: a first comparison based on fluorescence in situ hybridization. Appl Environ Microbiol 65:3721-3726

Guckert JB, Antworth CP, Nichols PD, White DC (1985) Phospholipid, ester-linked fatty acid profiles as reproducible assays for changes in prokaryotic community structure of estuarine sediments. FEMS Microbiol Ecol 31:147-158

Harvey HR (1994) Fatty acids and sterols as source markers of organic matter in sediments of the North Carolina continental slope. Deep-Sea Res II 41:783-796
Harvey HR, Macko SA (1997) Catalysts or contributors? Tracking bacterial mediation of early diagenesis in the marine water column. Org Geochem 26:531-544

Harvey HR, Mannino A (2001) The chemical composition and cycling of particulate and macromolecular dissolved organic matter in temperate estuaries as revealed by molecular organic tracers. Org Geochem 32:527-542

Harvey HR, McManus GB (1991) Marine ciliates as a widespread source of tetrahymanol and hopan-3-beta-ol in sediments. Geochim Cosmochim Acta 55:3387-3390

Kaneda T (1991) Iso- and anteiso-fatty acids in bacteria: biosynthesis, function, and taxonomic significance. Microbiol Rev 55:288-302

Kirchman DL (2000) Microbial ecology of the oceans. John Wiley \& Sons, New York

Kirchman DL (2002) The ecology of Cytophaga-Flavobacteria in aquatic environments. FEMS Microbiol Ecol 39:91-100

Kirchman DL, Dittel AI, Findlay SEG, Fischer D (2004) Changes in bacterial activity and community structure in response to dissolved organic matter in the Hudson River, New York. Aquat Microb Ecol 35:243-257

Kirchman DL, Dittel AI, Malmstrom RR, Cottrell MT (2005) Biogeography of major bacterial groups in the Delaware estuary. Limnol Oceanogr 50:1697-1706

Koga Y, Morii H, Akagawa-Matsushita M, Ohga M (1998) Correlation of polar lipid composition with 16S rRNA phylogeny in methanogens. Further analysis of lipid component parts. Biosci Biotechnol Biochem 62:230-236

Malmstrom RR, Cottrel MT, Elifantz H, Kirchman DL (2005) Biomass production and assimilation of dissolved organic matter by SAR11 bacteria in the Northwest Atlantic Ocean. Appl Environ Microbiol 71:2979-2986

Mannino A, Harvey HR (1999) Lipid composition in particulate and dissolved organic matter in the Delaware Estuary: sources and diagenetic patterns. Geochim Cosmochim Acta 63:2219-2235

Mergaert J, Verhelst A, Cnockaert MC, Tan TL, Swings J (2001) Characterization of facultative oligotrophic bacteria from polar seas by analysis of their fatty acids and $16 \mathrm{~S}$ rDNA sequences. Syst Appl Microbiol 24:98-107

Morris RM, Rappé MS, Connon SA, Vergin KL, Siebold WA, Carlson CA Giovannoni SJ (2002) SAR11 clade dominates ocean surface bacterioplankton communities. Nature 420: 806-810

Nichols PD, Guckert JB, White DC (1986) Determination of monounsaturated fatty acid double bond position and geometry for microbial monocultures and complex consortia by capillary GC-MS of their dimethyl disulfide adducts. J Microbiol Methods 5:49-55

Pennock JR, Sharp JH (1986) Phytoplankton production in the Delaware estuary: temporal and spatial variability. Mar Ecol Prog Ser 34:143-155

Ratledge C, Wilkenson SG (1989) Microbial lipids, Vol 2. Chapter 13. Biosynthesis of fatty acids and related compounds. Academic Press, New York, p 3-42

Sharp JH, Culberson CH, Church TM (1982) The chemistry of the Delaware estuary. General considerations. Limnol Oceanogr 27:1015-1028

Sharp JH, Cifuentes LA, Coffin RB, Pennock JR, Wong KC (1986) The influence of river variability on the circulation, chemistry, and microbiology of the Delaware Estuary. Estuaries 9:261-269

Sinninghe Damsté JS, Strous M, Rijpstra WIC, Hopmans EC, Geenevasen JAJ, van Duin ACT, van Niftrik LA, Jetten MSM (2002) Linearly concatenated cyclobutane lipids form a dense bacterial membrane. Nature 419:708-712

Sturt HF, Summons RE, Smith K, Elvert M, Hinrichs KU (2004) 
Intact polar membrane lipids in prokaryotes and sediments deciphered by high-performance liquid chromatography/ electrospray ionization multistage mass spectrometry - new biomarkers for biogeochemistry and microbial ecology. Rapid Commun Mass Spectrom 18:617-628

Suzuki MT, Rappé MS, Haimberger ZW, Winfield H, Adair N, Strobel J, Giovannoni SJ (1997) Bacterial diversity among small-subunit rRNA gene clones and cellular isolates from the same seawater sample. Appl Environ Microbiol 63: 983-989

Teece MA, Fogel ML, Dollhopf ME, Nealson KH (1999) Isotopic fractionation associated with biosynthesis of fatty acids by a marine bacterium under oxic and anoxic conditions. Org Geochem 30:1571-1579

Volkman JK (1986) A review of sterol markers for marine and terrigenous organic matter. Org Geochem 9:83-99

Editorial responsibility: Gerhard Herndl,

Den Burg, Texel, The Netherlands
Wakeham SG (1999) Monocarboxylic, dicarboxylic and hydroxy acids released by sequential treatments of suspended particles and sediments of the Black Sea. Org Geochem 30:1059-1074

Wakeham SG, Pease TK, Benner R (2003) Hydroxy fatty acids in marine dissolved organic matter as indicators of bacterial membrane material. Org Geochem 34:857-868

Zhang CL, Li Y, Ye Q, Fong J and 5 others (2003) Carbon isotope signatures of fatty acids in Geobacter metallireducens and Shewanella algae. Chem Geol 195:17-28

Zou L, Wang XC, Callahan J, Culp RA, Chen RF, Altabet MA, Sun MY (2004) Bacterial roles in the formation of highmolecular-weight dissolved organic matter in estuarine and coastal waters: evidence from lipids and the compound-specific isotopic ratios. Limnol Oceanogr 49: 297-302

Submitted: May 26, 2005; Accepted: November 7, 2005

Proofs received from author(s): February 15, 2006 